[Agr. Biol. Chem., Vol. 36, No. 11, p. 2025 2026, 1972]

\title{
Requirements for Nutrients and Minerals by Candida brumptii IFO 0731 Producing Succinic Acid from n-Paraffin
}

\author{
By Mikio Sato, Tadaatsu Nakahara and Koichi Yamada \\ Department of Agricultural Chemistry, Faculty of Agriculture, \\ The University of Tokyo, Tokyo \\ Received April 11, 1972
}

It has been reported in a previous paper ${ }^{1}$ that Candida brumptii IFO 0731 produced succinic acid in large quantity $(23.6 \mathrm{mg} / \mathrm{ml})$ from super heavy $n$-paraffin and the productivity was markedly increased by the addition of organic nutrients such as corn steep liquor. It was suggested from the observation of no growth in the absence of corn steep liquor that organic nutrient(s) or trace mineral(s) might be required for cell growth and succinic acid production.

The purpose of the present note is to investigate the nutrient and mineral requirements of this strain in detail.

The compositions of the basal medium were as follows: $50 \mathrm{ml}$ of $n$-paraffin, the compositions of which were described in the previous paper, ${ }^{1)} 0.5 \mathrm{~g}$ of $\mathrm{NH}_{4} \mathrm{Cl} ; 0.5 \mathrm{~g}$ of $\mathrm{KH}_{2} \mathrm{PO}_{4}$; $0.8 \mathrm{~g}$ of $\mathrm{MgSO}_{4} \cdot 7 \mathrm{H}_{2} \mathrm{O} ; 0.1 \mathrm{~g}$ of $\mathrm{MnSO}_{4} \cdot 4 \mathrm{H}_{2} \mathrm{O}$ and $50 \mathrm{~g}$ of $\mathrm{CaCO}_{3}$ per liter of deionized water ( $\mathrm{pH}$ 6.3). The preparation of ashes was conducted in the following method.

One ml of corn steep liquor (Nihon Shokuhin Kako Co., Ltd.), placed in a crucible porcelain, was dried at $80^{\circ} \mathrm{C}$ overnight and was treated with heat on a gas-burner until ashes were remained white. One $\mathrm{ml}$ of deionized water was added to this preparation. C. brumptii cells were grown at $30^{\circ} \mathrm{C}$ with shaking in a malt extract broth as described previously." The cells, cultured for $48 \mathrm{hr}$, were harvested by centrifugation at $2000 \times g$ for $5 \mathrm{~min}$ at $5^{\circ} \mathrm{C}$, washed once with deionized water and suspend- ed in the same volume of water as the culture broth. One tenth $\mathrm{ml}$ of above suspension was inoculated into the basal medium supplemented with a mixture of vitamins $(4 \mathrm{mg}$ of Ca-pantothenate, of inositol, of pyridoxine$\mathrm{HCl}$ and of nicotinic acid; $25 \mathrm{mg}$ of thiamine$\mathrm{HCl}$ and $0.4 \mathrm{mg}$ of biotin per liter medium in the final concentration) and trace minerals (500 $\mu \mathrm{g}$ of $\mathrm{H}_{3} \mathrm{BO}_{3} ; 50 \mu \mathrm{g}$ of $\mathrm{CuSO}_{4} \cdot 5 \mathrm{H}_{2} \mathrm{O} ; 100$ $\mu \mathrm{g}$ of $\mathrm{KI} ; 200 \mu \mathrm{g}$ of $\mathrm{Na}_{2} \mathrm{MoO}_{4} \cdot 2 \mathrm{H}_{2} \mathrm{O} ; 400 \mu \mathrm{g}$ of $\mathrm{ZnSO}_{4} \cdot 7 \mathrm{H}_{2} \mathrm{O}$ and $100 \mu \mathrm{g}$ of $\mathrm{CoSO}_{4} \cdot 7 \mathrm{H}_{2} \mathrm{O}$ per liter medium in the final concentration), unless otherwise stated. Incubation was conducted for 7 days as described previously. ${ }^{1}$ Determinations of succinic acid, cell growth and residual $n$-paraffin were carried out as reported. ${ }^{1}$

Whether the effect of corn steep liquor observed previously ${ }^{13}$ could be substituted for other compounds or not was investigated. The results were summarized in Table $\mathbf{I}$. It was found that the effect of corn steep liquor was almost replaced by both trace minerals and vitamins. No growth or scanty growth was observed with the supplemented medium with mineral or vitamin mixture alone, which suggests that the cell growth requires both minerals and vitamins. Table II shows the effect of omission of each vitamin on the cell growth and succinic acid production. It turned out that biotin was absolutely required for cell growth and thiamine partially or adaptively. Omission of panthothenate re- 
Table I. Effect of Ashes and Vitamins on Succinic Acid Production.

C. brumptii cells were cultured at $30^{\circ} \mathrm{C}$ for 7 days in the basal medium supplemented with the indicated additives. The concentration of corn steep liquor was $1 \mathrm{ml} /$ liter. Ashes, obtained from $1 \mathrm{ml}$ of corn steep liquor, was added to 1 liter medium.

\begin{tabular}{lccc}
$\begin{array}{c}\text { Additives to } \\
\text { basal medium }\end{array}$ & Final pH & $\begin{array}{c}\text { Dried } \\
\text { cell wt. } \\
(\mathrm{mg} / \mathrm{ml})\end{array}$ & $\begin{array}{c}\text { Succinic } \\
\text { acid } \\
(\mathrm{mg} / \mathrm{ml})\end{array}$ \\
\hline $\begin{array}{l}\text { Corn steep liquor } \\
\text { Ashes }\end{array}$ & 5.40 & 4.8 & 8.0 \\
$\begin{array}{l}\text { Ashes + Vitamins } \\
\text { Trace minerals }\end{array}$ & 5.99 & 4.8 & -6.6 \\
$\begin{array}{l}\text { Trace minerals } \\
+ \text { Vitamins }\end{array}$ & 6.10 & 4.8 & 6.0 \\
Vitamins & 6.26 & 0.2 & 0 \\
\hline
\end{tabular}

a) No growth.

Table II. Effect of a Vitamin Omission on Cell Growth and Succinic Acid Productivity

C. brumptii cells were cultured at $30^{\circ} \mathrm{C}$ for 7 days in the basal medium supplemented with 6 trace minerals and the indicated vitamins mixture. When 6 vitamins were all included in the medium, the vitamins mixture was represented as complete. Yield was determined as previously described. ${ }^{11}$

\begin{tabular}{|c|c|c|c|c|}
\hline Vitamins & $\begin{array}{c}\text { Final } \\
\mathrm{pH}\end{array}$ & $\begin{array}{l}\text { Dried } \\
\text { cell wt. } \\
(\mathrm{mg} / \mathrm{ml})\end{array}$ & $\begin{array}{c}\text { Succinic } \\
\text { acid } \\
(\mathrm{mg} / \mathrm{ml})\end{array}$ & $\begin{array}{l}\text { Yield } \\
(\%)\end{array}$ \\
\hline Complete & 6.15 & 4.3 & 6.1 & 30 \\
\hline Biotin omitted & - $^{\prime}$ & - & - & - \\
\hline $\begin{array}{l}\text { Nicotinic acid } \\
\text { omitted }\end{array}$ & 6.12 & 3.6 & 6.2 & 30 \\
\hline $\begin{array}{l}\text { Ca-pantothenate } \\
\text { omitted }\end{array}$ & 6.20 & 4.4 & 0.7 & 5 \\
\hline $\begin{array}{l}\text { Pyridoxine-HCl } \\
\text { omitted }\end{array}$ & 6.13 & 3.8 & 2.1 & 21 \\
\hline Inositol omitted & 6.17 & 4.1 & 1.7 & 17 \\
\hline $\begin{array}{l}\text { Thiamine- } \mathrm{HCl} \\
\text { omitted }\end{array}$ & 6.12 & 2.6 & 3.2 & 20 \\
\hline
\end{tabular}

a) No growth. sulted in a significant decrease in the succinic acid production and yield, although cell growth was unaffected. As shown in Table III, scanty growth was also observed in the ab.

\section{Table III. Effect of a Trace Mineral Omission} on Cell Growth and Succinlc

\section{Acid Productivity}

C. brumptii cells were cultured at $30^{\circ} \mathrm{C}$ for 7 days in the basal medium supplemented with 6 vitamins and the indicated minerals. When 6 minerals were all included in the medium, the minerals mixture was represented as complete.

\begin{tabular}{lcccr}
\hline \multicolumn{1}{c}{ Minerals } & $\begin{array}{c}\text { Final } \\
\text { pH }\end{array}$ & $\begin{array}{c}\text { Dried } \\
\text { cell wt. } \\
(\mathrm{mg} / \mathrm{ml})\end{array}$ & $\begin{array}{c}\text { Succinic } \\
\text { acid } \\
(\mathrm{mg} / \mathrm{ml})\end{array}$ & $\begin{array}{c}\text { Yield } \\
(\%)\end{array}$ \\
\hline Complete & 6.00 & 4.7 & 7.0 & 33 \\
$\mathrm{CoSO}_{4}$ omitted & 5.90 & 4.2 & 5.9 & 29 \\
$\mathrm{CuSO}_{4}$ omitted & 5.83 & 4.5 & 5.8 & 23 \\
$\mathrm{H}_{3} \mathrm{BO}_{3}$ omitted & 6.11 & 2.1 & 0.8 & 7 \\
$\mathrm{KI} \mathrm{omitted}$ & 6.10 & 1.1 & 0.1 & 1 \\
$\mathrm{Na}_{2} \mathrm{MoO}_{4}$ omitted & 5.90 & 4.3 & 5.6 & 22 \\
$\mathrm{ZnSO}_{4}$ omitted & 6.06 & 4.2 & 2.3 & 9 \\
\hline
\end{tabular}

sence of potassium iodide. Omission of boric acid resulted in a remarkable decrease in the succinic acid production and yield, compared with the decrease in cell growth. It may be said that potassium iodide is absolutely required for cell growth, although calcium carbonate, which was added at the concentration of $50 \mathrm{~g}$ per liter, is contaminated by small amounts of impurities. We will investigate the details hereafter.

\section{REFERENCE}

1) M. Sato, T. Nakahara and K. Yamada, Agr. Biol. Chem., in press. 